\title{
Climate Change, Development Projects and Internal Displacement In Africa
}

\author{
Romola Adeola* \\ University of Pretoria aderomola.ade@gmail.com \\ Frans Viljoen** \\ University of Pretoria frans.viljoen@up.ac.za
}

\begin{abstract}
Given the need for legislation to protect internally displaced persons, African Heads of State and Government adopted the Convention on the Protection and Assistance of Internally Displaced Persons in Africa in Kampala in October 2009. The convention, which entered into force on 6 December 2012, is the first international binding instrument on internal displacement. Article 10 of the convention requires states to prevent displacement caused by development projects, including climate-based development projects. This article examines the content of this obligation within the context of climate-based development projects.
\end{abstract}

\section{Keywords}

Climate-based development-induced displacement, climate change, internal displacement, Kampala Convention, Africa

\section{Introduction}

In response to the challenge of internal displacement in Africa, the African Union Assembly of Heads of State and Government (AU Assembly) adopted the Convention on the Protection and Assistance of Internally Displaced Persons in October 2009 (the Convention) ${ }^{1}$ as a regional legal framework for

\footnotetext{
* LLM, LLD (Pretoria). Postdoctoral fellow, Centre for Human Rights, Faculty of Law, University of Pretoria.

* LLM (Cantab); MA, LLD (Pretoria). Director and professor of international human rights law, Centre for Human Rights, Faculty of Law, University of Pretoria.

1 As of August 2018, the last ratification of the Convention was on 24 May 2017. As at 24 May 2017, at total of 40 African Union member states had signed the Convention and 27 had ratified it. See "List of countries which have signed, ratified / acceded to the African Union Convention for the Protection and Assistance of Internally Displaced Persons in Africa", available at: <https://au.int/sites/default/files/treaties/7796-sl-african_union_ convention_for_the_protection_and_assistance_of_internally.pdf> (last accessed 26 August 2018).
} 
addressing the problem. ${ }^{2}$ The Convention recognizes several root causes of internal displacement, including conflict, harmful practices, disaster and development-induced displacement (DID). Within the context of DID, this article focuses on climate-based DID (CBDID), which is the forced removal of individuals and communities from their places of habitual residence to make way for the pursuit of sustainable development projects intended for the furtherance of climate change mitigation and adaptation measures. These measures are aligned with the UN Framework Convention on Climate Change (Framework Convention), which directs states to achieve "stabilization of greenhouse gas concentrations in the atmosphere at a level that would prevent dangerous anthropogenic interference with the climate system". ${ }^{3}$ Based on the principle of common but differentiated responsibilities, developed states are required to reduce global emissions and address climate change impacts owing to their historical responsibility.

In implementing this objective, the Kyoto Protocol ${ }^{4}$ establishes certain flexibility measures by which developed states can meet their obligations. One of these measures is the Clean Development Mechanism (CDM), which aims to promote clean and sustainable development in developing countries. Through CDMs, developed states can offset carbon emissions in developing states by purchasing certified emission credits from emission reduction projects; developing states can use the proceeds to advance economic growth. With a similar objective to the CDM, projects under the UN Reduction of Emissions from Deforestation and Forest Degradation programme (REDD+) are geared towards reducing carbon emissions by increasing forest carbon sinks. ${ }^{5}$ However, these projects have resulted in displacement and restricted access to land in developing countries, many of which are in the global South, including in Africa. ${ }^{6}$ In pursuing the benefit of these projects, African states have often leaned in favour of development project imperatives at the cost of concern for the rights of displaced persons.

The Convention requires states to protect the rights of internally displaced persons (IDPs), including populations displaced by climate change. ${ }^{7}$ Although the Convention does not specifically articulate what needs to be

2 F Viljoen International Human Rights Law in Africa (2nd ed, 2012, Oxford University Press) at $347-49$.

3 Framework Convention (1992), art 2.

4 Kyoto Protocol to the Framework Convention, adopted by the Conference of State Parties to the UN Framework Convention (11 December 1998)

5 The Cancun Agreements: Outcome of the Work of the Ad Hoc Working Group on Long-term Cooperative Action under the Convention, adopted at the 16th session of the UN Framework Convention Conference of the Parties, Cancun, Mexico (29 November - 10 December 2010).

6 D Abbott and G Wilson The Lived Experience of Climate Change: Knowledge, Science and Public Action (2015, Springer); DS Olawuyi The Human Rights-Based Approach to Carbon Finance (2016, Cambridge University Press) at 9.

7 See R Adeola "The right not to be arbitrarily displaced under the United Nations Guiding Principles on Internal Displacement” (2016) 16/1 African Human Rights Law Journal 83. 
done to protect persons displaced by climate change, article 10(1) requires states "as much as possible" to prevent CBDID. However, neither the Convention nor the Model Law for the Implementation of the Convention, ${ }^{8}$ adopted by the AU Assembly in January 2018, sets a yardstick for what "as much as possible" entails. Furthermore, the Convention does not describe the nature of states' obligation in respect of acts by private actors and does not contain guidelines on how states should regulate private actors implicated in CBDID. Literature on internal displacement in Africa largely focuses on conflict, overlooking the issue of DID, particularly CBDID. ${ }^{9}$

While article 10(1) seeks to prevent CBDID, it is not clear what states should do to ensure that this obligation is met. This article argues that an understanding of the obligation in this provision should be considered in the context of the Convention's objective, which is to prevent arbitrary displacement. While the Convention does not place an absolute prohibition on displacement, it categorically prohibits arbitrary displacement. This article discusses the constitutive elements of arbitrary displacement under the Convention within the context of CBDID. Before embarking on the discussion, it considers some trends in CBDID in Africa, after which a systematic exposition is made of the norms pertaining to the legal protection of climate-based development-induced displaced persons (CBDIDPs) in Africa.

\section{Trends in climate-based development-induced displacement in Africa}

Since the 20th century, large scale development projects have been considered essential to achieve Africa's industrialization. However, these projects have often come at significant human cost, exemplified by inadequate compensation, insufficient consultation and improper resettlement. Across Africa, developmental projects have significantly impacted on the livelihood capacities of local communities and occasioned population displacement. Examples abound. In Mozambique, over 2,000 families were displaced between 2009 and 2014 in the Tete province for coal extraction; although resettlement was planned, farmland provided in certain instances was not

8 AU Model Law for the Implementation of the AU Convention for the Protection of and Assistance to Internally Displaced Persons in Africa (2018) (AU Model Law).

9 In instances where reference is made to the subject, the nature of states' obligation under art 10 of the Convention is not clearly articulated. See SA Nuhu "Development induced displacement in the African context: What says the African Union Convention?" (2012) 2/1 Journal of Internal Displacement 6 at 15; L Juma "Protection of development-induced internally displaced persons under the African Charter: The case of the Endorois community of northern Kenya" (2013) 46 Comparative and International Law of Southern Africa 211; A Abebe The Emerging Law on Forced Displacement in Africa: Development and Implementation of the Kampala Convention on Internal Displacement (1st ed, 2016, Routledge) at 157. 
suitable for agricultural production. ${ }^{10}$ More than 1,000 families were displaced for copper mining in the north-western province of Zambia without adequate compensation; this particularly affected women. ${ }^{11}$ In Egypt, over 2,000 people were displaced without proper compensation to make way for the New Suez Canal project in $2014 . .^{12}$ In Angola, about 30,000 people were displaced between 2002 and 2006 for housing projects. ${ }^{13}$ More than 10,000 people were displaced from the Bole Bubula area in Ethiopia to make way for the Addis Ababa airport in 2002. ${ }^{14}$

With the emergence of climate change and the need to reverse its negative impact, states are increasingly embarking on climate-based development projects. These projects can also occasion displacement. Through the World Bank's Forest Carbon Partnership Facility, the REDD+ programme and other private sector partnerships, projects on afforestation, renewable energy and forest conservation have become imperatives in adapting and mitigating climate change impacts. ${ }^{15}$ Regrettably, they have also come at a human cost, as issues of inadequate notice, cosmetic consultation, improper compensation and resettlements have characterized their implementation. In Madagascar and Tanzania, for instance, REDD+ projects have significantly impacted the livelihood capacities of local communities, not least in relation to access to agricultural land and natural resources. ${ }^{16}$ In the Democratic Republic of Congo (DRC), one of the arguments adduced in support of the Inga Dam III is its potential to offset carbon emissions. ${ }^{17}$ However, displaced communities

10 M Lopes "Miners Vale, Rio Tinto accused of neglecting displaced Mozambicans" (23 May 2013) Reuters.

11 M Mis "Women pay the price for Zambia mining expansion" (15 September 2015) Reuters.

12 P Kingsley "Egypt to build new Suez Canal" (5 August 2014) The Guardian, available at: <https://www.theguardian.com/world/2014/aug/05/egypt-build-new-suez-canal> (last assessed 11 August 2018); P Kingsley and M Abdo "Thousands of Egyptians evicted without compensation for Suez project" (3 September 2014) The Guardian, available at: <https://www.theguardian.com/world/2014/sep/03/egyptians-evicted-without-compensationsuez-canal-project> (last assessed 11 August 2018); “'New Suez Canal' construction displaces over 2,000 people in Egypt" (1 October 2014) Middle East Eye, available at: <https://www.middleeasteye.net/news/new-suez-canal-construction-displaces-over-2000people-egypt-317681478> (last assessed 11 August 2018).

13 Human Rights Watch “They pushed down the houses': Forced evictions and insecure land tenure for Luanda's urban poor" (15 May 2007) at 8.

14 Centre on Housing Rights and Evictions "Housing rights for everyone, anywhere" (August 2005) 1/3 Evictions Monitor 1 at 10.

15 MM Bayrak and LM Marafa "Ten years of REDD+: A critical review of the impact of REDD+ on forest-dependent communities" (2016) 8/7 Sustainability 620.

16 Les Amis de La Terre "REDD+ in Madagascar: You can't see the wood for the carbon: Field study in Madagascar" (July 2013); S Pritchard "Evicted by charity” (1 December 2014) New Internationalist, available at: <https://newint.org/features/2014/12/01/evicted-by-charity> (last assessed 11 August 2018); JF Lund et al "Promising change, delivering continuity: REDD+ as conservation fad" (2017) 89 World Development 124.

17 "Congo, DR: Inga Dams mean big business for corporations and no benefit for local communities" (30 January 2009) 138 World Rainforest Movement Bulletin, available at: $<$ https://wrm.org.uy/articles-from-the-wrm-bulletin/section1/congo-d-r-inga-dams-mean- 
from the construction of the Inga Dams I and II in the 1970s are yet to be properly compensated after more than four decades. ${ }^{18}$ Across Africa, cases of CBDID have followed similar patterns.

The case of the Sengwer peoples in Kenya illustrates this challenge. In 2007, the Kenyan government initiated a Natural Resource Management Programme (NRMP) with technical assistance for REDD+ readiness from the World Bank. ${ }^{19}$ The aim of the project was to enhance carbon sinks through forest conservation and to prevent forest degradation and depletion of forest resources for the promotion of economic activities in the country. ${ }^{20}$ Given that it was to be implemented on indigenous peoples' territories, an Indigenous Peoples' Planning Framework was developed with the aim of fostering the participation of "forest and resettlement related committees, working groups and other decision making bodies". ${ }^{21}$ In contravention of this framework and a court order prohibiting displacement, ${ }^{22}$ government authorities torched several homes belonging to the Sengwer indigenous peoples in the Embobut forest in furtherance of the NRMP. ${ }^{23}$

In the DRC, CDM projects have had similar impacts, particularly on the Batwa (Pygmies). The Ibi-Batéké Carbon Sink Plantation (IBCSP) is a case in point. ${ }^{24}$ Following the DRC's ratification of the Kyoto Protocol in 2005, the IBCSP was initiated as a CDM project to promote reforestation, contribute to fuel-wood supplies to Kinshasa and enhance carbon sinks "capable of

contd

big-business-for-corporations-and-no-benefit-for-local-communities/> (last accessed 11 August 2018).

18 International Rivers Infrastructure for Whom? A Critique of the Infrastructure Strategies of the Group of 20 and the World Bank (2012, International Rivers Publications) at 13.

19 World Bank "Report and recommendation: Kenya: Natural resource management project" (World Bank report no 77959-KE, World Bank Inspection Panel, 29 May 2013) at 24.

20 World Bank "Project appraisal document on a proposed credit in the amount of SDR46.0 million (approximately US\$68.5 million) to the government of Kenya for a natural resource management project" (World Bank report no 37982-KE, SD Operations for Eastern Africa, Eastern Africa Country Cluster Two, Africa Region, World Bank, 26 February 2007) at 1.

21 Republic of Kenya "Indigenous peoples planning framework for the western Kenya community driven development and flood mitigation project and the natural resource management project" (2006).

22 Conservatory Orders (26 March 2013) by Justice Fred Ochieng in Eldoret High Court, petition no 6 of 2013 David Kiptum Yator and Others (on Behalf of the Sengwer Community) $v$ Kenya Forest Services and Others.

23 A Langat "On the edge of home: The forcible evictions of the Sengwer in Kenya" (28 April 2014) Think Africa Press, available at: <https://allafrica.com/stories/201404290595.html> (last accessed 11 August 2018).

24 SM Adrien "The DRC case study: The impact of the Carbon Sinks of Ibi-Batéké Project on the indigenous Pygmies of the Democratic Republic of Congo" in M Abhainn, KM Bernard and S Grey (eds) Indigenous Peoples and Climate Change: Vulnerabilities, Adaptation and Responses to Mechanisms of the Kyoto Protocol: A Collection of Case Studies (2007, The International Alliance of Indigenous and Tribal Peoples of the Tropical Forests) 45 . 
sequestering around 2.5 million of tons of $\mathrm{CO}_{2}$ eq [carbon dioxide equivalent] over 30 years". ${ }^{25}$ For CDM projects to be acceptable within the context of the Kyoto Protocol, proponents of the project must develop a descriptive document that details the project's socio-economic and environmental impact. ${ }^{26}$ Following an examination of this document, the designated national authority issues a "letter of no objection" that reflects the government's endorsement of the project. ${ }^{27}$ While the proponents of the CDM project obtained the required letter, the consultation process with the Batwa on the Batéké plateau was significantly flawed. ${ }^{28}$ Proponents indicated that "an extensive consultation was carried out with the local populations, local institutions and nongovernmental organisations". ${ }^{29}$ However, evaluation conducted by civil society with the aim of assessing the involvement of indigenous populations in the project revealed that the Batwa were not involved in the preparation of the project. ${ }^{30}$ Not only were Batwa lands plundered, CDM activities also resulted in land expropriation. ${ }^{31}$ As with the Batwa, forest communities in the Mai-Ndombe province in the DRC have also been poorly consulted. In a report by the Rights and Resources Initiative, it was observed that most of the consultative processes take place in Kinshasa, limiting the effective participation of these rural communities. ${ }^{32}$

In Uganda, the case of the UK-based New Forests Company reflects the complicity of businesses in this form of displacement. In 2005, the New Forests Company was granted a licence to establish three timber plantations in the Ugandan districts of Bugiri, Kiboga and Mubende. ${ }^{33}$ This project was geared towards planting trees, selling timber and gaining carbon credits. In 2011, more than 20,000 people were displaced for the project without adequate compensation. ${ }^{34}$ While the New Forest Company claimed in its project design document form submitted to UN-CDM that the evictions were voluntary, ${ }^{35}$ the

25 O Mushieta and A Merrill "IBI Batéké Carbon Sink Plantation: An African forestry pilot case" (2010) 4/4 Carbon and Climate Law Review 351 at 352.

26 Adrien "The DRC case study", above at note 24 at 60.

27 Ibid.

28 Id at 61-62.

29 Mushieta and Merrill "IBI Batéké Carbon Sink Plantation", above at note 25 at 355.

30 Adrien "The DRC case study", above at note 24 at 61.

31 Id at 65.

32 M Gauthier "Mai-Ndombe: Will the REDD+ laboratory benefit indigenous peoples and local communities: Analysis of the cumulative impact and risks of REDD+ initiatives" (2018, Rights and Resources Initiative) at 8.

33 M Grainger and K Geary "The New Forests Company and its Uganda plantations" (2011, Oxfam International) at 3.

34 J Vidal "Ugandan farmer: 'My land gave me everything. Now I'm one of the poorest"' (22 September 2011) The Guardian, available at: <https://www.theguardian.com/ environment/2011/sep/22/uganda-farmer-land-gave-me-everything> (last assessed 11 August 2018).

35 CDM - Executive Board "Clean development mechanism: Project design document form: For afforestation and reforestation project activities” (CDM-AR-PADD, version 05) at 132. 
accounts of the local populations, speaking of physical violence and destruction of property, were contradictory. ${ }^{36}$

By requiring states to protect persons displaced by climate change, article 5 (4) of the Convention seeks to address these situations. Article 5(4) represents the first binding legal obligation for states to protect persons displaced by climate change. Although it does not specify the nature of protection, the implication of this provision, read in conjunction with article 10 , is that states must ensure that a balance is struck between climate-based development imperatives and the rights of CBDIDPs. However, article 10 of the Convention does not elaborate on how this balance should be struck. Placing the provision in the context of international law, this article now aims to advance clarity on the issue.

\section{Article 10(1) of the Convention}

Under article 10(1) of the Convention, African states are required "as much as possible" to prevent CBDID. A literal meaning of the term ${ }^{37}$ suggests that states should "to the greatest measure, or in the largest amount possible", ${ }^{38}$ prevent this form of displacement. However, as the Convention does not define the phrase "as much as possible", it is not clear by what standard the "greatest measure" should be assessed, or by what yardstick the "largest amount possible" should be considered. A combined reading of article 10(1) with articles 3(1)(a), 4(1) and 4(4) of the Convention indicates that states are required to ensure that CBDID is not arbitrary. The authors contend that this obligation requires states to ensure that the due process of law is followed. ${ }^{39}$ In the Case Concerning Elettronica Sicula, the International Court of Justice established a threshold for understanding the meaning of "arbitrary", stating that an act will be arbitrary where there is "a wilful disregard of due process of law". ${ }^{40} \mathrm{On}$ this basis, the arbitrary nature of an act must be measured in the context of compliance with the due process of law.

The concept of due process of law is intrinsically woven into the idea of natural justice. Due process involves an expectation that a state will act legitimately. ${ }^{41}$ Within the context of internal displacement, due process contemplates the minimum procedural requirements that must be followed to

36 Grainger and Geary "The New Forests Company", above at note 33 at 4.

37 See Vienna Convention on the Law of Treaties 1969, 1155 UNTS 331, art 31(1).

38 See Macmillan Dictionary at: <http://www.macmillandictionary.com/thesauruscategory/british/as-much-as-possible> (last accessed 8 July 2018).

39 See R Adeola and F Viljoen "The right not to be arbitrarily displaced in Africa” (2017) 25/4 African Journal of International and Comparative Law in Africa 459 at 473-75.

40 Case Concerning Elettronica Sicula SpA (ELSI) (United States of America $v$ Italy) ICJ (20 November 1950) (1950) ICJ general list no 76, para 128.

41 NJ Udombana "The African Commission on Human and Peoples' Rights and the development of fair trial in Africa” (2006) 6 African Human Rights Law Journal 299 at 300. 
prevent arbitrary displacement. ${ }^{42}$ But what are these due process requirements in the determination of arbitrary or non-arbitrary CBDID? These requirements are discussed in the next sections, with reference to articles 10 (2) and 10(3) of the Convention.

\section{Prior-impact assessments}

Article 10(3) of the Convention instructs states to carry out socio-economic and environmental impact assessments before the implementation of projects. The rationale for article 10(3) in the context of the least restrictive means element is that, in order to understand the "restrictive" implications of a project on rights, it is important to conduct prior socio-economic and environmental impact assessments. ${ }^{43}$

The socio-economic impacts of a project are the likely consequences that a project may have on the social ordering and the economic sustenance of persons likely to be displaced. From an interdisciplinary perspective, two categories of impact are contemplated, namely social impact and economic impact. In the field of social sciences, Armour describes social impact as alterations in people's lifestyle, culture and community. Building on this definition, Vanclay describes social impact as changes in lifestyle, cultural and political systems, well-being, property rights, environment and aspirations. ${ }^{44}$ In the Guidelines and Principles for Social Impact Assessment developed by the Inter-Organisational Committee on Guidelines and Principles for Social Impact Assessment, social impacts are described as "the consequences to human populations of any public or private actions that alter the ways in which people live, work, play, relate to one another, organize to meet their needs and generally cope as members of society". ${ }^{45}$

While these definitions offer a basis on which to understand social impact, the social variables contemplated by these definitions such as play, aspirations, relationships and lifestyle remain difficult to quantify. Indeed, Sairinen's assertion that "social impacts are ... perceived differently by different people through socially-mediated understandings of what is 'normal' or

42 UN Guiding Principles on Internal Displacement, UN doc E/CN.4/1998/53/Add.1 (1998) (Guiding Principles), para 88.

43 The Zambian Guidelines for Compensation and Resettlement of Internally Displaced Persons, while not specifically mentioning the types of impact assessments that should be conducted in DID situations, require the Department of Resettlement to "carry out an assessment and / or verification on the potential displacements" of development projects. See Zambian Guidelines for Compensation and Resettlement of Internally Displaced Persons (IDPs), 2013 (Zambian Guidelines), para 29(i).

44 F Vanclay "International principles for social impact assessment" (2003) 21/1 Impact Assessment and Project Appraisal 5 at 8.

45 Inter-Organisational Committee on Guidelines and Principles for Social Impact Assessment "Guidelines and principles for social impact assessment" (1995) 15/1 Environmental Impact Assessment Review 11. 
'natural' or 'to be expected' or even 'acceptable"',46 is a reminder that assessing this form of impact can be daunting.

Economic impacts are more definite in that they relate to the material and financial resources for sustaining livelihood capacities. However, there are no set benchmark for assessing the economic impacts of CBDID specifically. This gap is evident in light of the fact that literature on the impacts of CBDID from an economic perspective is scanty.

In determining the benchmark against which the social and economic impacts of CBDID should be assessed in light of article 10(3), reference should be made to the social variables in consultation with persons likely to be displaced and also to the socio-economic rights obligations of states. The authors contend that socio-economic rights (such as the rights to an adequate standard of living, ${ }^{47}$ work, ${ }^{48}$ health, ${ }^{49}$ development, ${ }^{50}$ education, ${ }^{51}$ culture ${ }^{52}$ and social security) ${ }^{53}$ should be taken into consideration in conducting socioeconomic impact assessments under article 10(3) of the Convention. This argument derives from the fact that there is an obligation on states to respect the human rights obligations that necessarily flow from their obligation to prevent internal displacement. ${ }^{54}$

The need for an environmental impact assessment (EIA) before a development project is implemented derives from the fact that harming the environment can affect the livelihood capacities of those dependent on it. Moreover, in light of the right to the environment contained in soft law standards and specifically recognized in the African Charter on Human and Peoples' Rights (African Charter), the need for states to conduct EIAs before implementing development projects resonates. Article 24 of the African Charter requires that "all peoples shall have the right to a general satisfactory environment". In SERAP, 55 the Economic Community of West African States (ECOWAS) Court of Justice noted that this provision must be read in line with article 1

46 R Sairinen "Assessing social impacts of urban land-use plans: From theory to practice" (2005) 9 Boreal Environment Research 509 at 510.

47 International Covenant on Economic, Social and Cultural Rights, adopted by UN General Assembly res 2200A (XXI), UN doc A/6316 (16 December 1966) (ICESCR), art 11(1).

48 Id, art 6; African Charter on Human and Peoples' Rights, adopted by the Organisation of African Unity, OAU doc CAB/LEG/67/3 rev 5 (27 June 1981) (African Charter), art 15.

49 ICESCR, art 12; African Charter, art 16.

50 Declaration on the Right to Development, adopted by UN General Assembly res 41/128, UN doc A/RES/41/128 (4 December 1986) (Development Declaration), art 1; African Charter, art 22.

51 ICESCR, art 13; Convention on the Rights of the Child (1989) 1577 UNTS 3, art 28; African Charter, art 17(1).

52 ICESCR, art 15(a); African Charter, art 17(2); Universal Declaration of Human Rights, adopted by UN General Assembly res 217 A(III) of 10 December 1948, art 27(1).

53 ICESCR, art 9.

54 The Convention, art 4(1).

55 Socio-Economic Rights and Accountability Project (SERAP) v Nigeria ECW/CCJ/JUD/18/12 (SERAP). 
of the African Charter, which obliges states to take "legislative or other measures" to realize the rights in the African Charter. Other measures, in the context of this provision, contemplate a wide range of means for the implementation of the obligations in the African Charter. In Ogoniland, the African Commission on Human and Peoples' Rights (African Commission) emphasized that " $\mathrm{t}]$ he right to a general satisfactory environment, as guaranteed under article 24 of the African Charter ... requires the state to take ... measures to prevent pollution and ecological degradation". ${ }^{56}$ Since the primary objective of carrying out an EIA is to evaluate the environmental consequences of proposed projects, it is an important measure in preventing pollution and ecological degradation and, as such, states must ensure that it is carried out.

\section{Information}

Article 10(2) of the Convention requires that, to prevent arbitrary CBDID, persons likely to be displaced must be fully informed about the project. ${ }^{57}$ Article 10(2) of the Convention emphasizes this requirement. CBDIDPs should actively participate in the exploration of feasible alternatives to the climate change adaptation and mitigation projects that are likely to displace them. As an enabling right, ${ }^{58}$ information serves as a basis for empowering persons likely to be displaced, which is a prerequisite for legitimizing the process of consultation and reaching informed decisions.

According to the Model Law on Access to Information for Africa (ATI Model Law), which "serves as a benchmark for measuring compliance with regional and international human rights standards", 59 information entails "[a]ny original or copy of documentary material irrespective of its physical characteristics ... and any other tangible or intangible material, regardless of the form ... in which it is held". ${ }^{60}$ Article 7 of the ATI Model Law requires that information must be provided relating to the policies and operations of public and private bodies, and those setting out processes of engagement with the public. In the prevention of arbitrary CBDID, any vital piece of material relating to the project and, significantly, its impact on persons likely to be displaced must be provided. ${ }^{61}$

56 Social and Economic Rights Action Centre (SERAC) and Another v Nigeria (2001) AHRLR 60 (ACHPR 2001) (Ogoniland), para 52.

57 This due process requirement is recognized under the Ugandan Policy on Internal Displacement as integral to the provision of sustainable solutions in situations of internal displacement. See Ugandan National Policy for Internally Displaced Persons, 2004, para 3.4(2).

58 UN General Assembly Report of the Special Rapporteur on the Promotion and Protection of the Right to Freedom of Opinion and Expression, Mr Frank La Rue, UN doc A/68/362 (4 September 2013), para 19.

59 ATI Model Law (2013, African Commission on Human and Peoples' Rights) at 11.

$60 \mathrm{Id}$, art 1.

61 Art 18(2) of the AU Model Law (above at note 8) lends further credence to this assertion in 


\section{Consultation}

Another key due process requirement for the prevention of arbitrary CBDID is that states must ensure that consultation is conducted with persons likely to be displaced before the implementation of climate-based development projects. ${ }^{62}$ In development practice, consultation is often regarded as "the weakest form of participation in decision-making". ${ }^{63}$ Cornwall observes that consultation "is widely used, north and south, as a means of legitimating alreadytaken decisions" ${ }^{64}$ Consultation, as a weak form of participation, is conceived as a process through which CBDIDPs are merely to give opinions or express their feelings on the climate-based projects "but are not involved in decisionmaking or implementation of projects". ${ }^{65}$ However, as a due process requirement in avoiding arbitrary CBDID, a relevant question that needs answering is whether consultation should be regarded as a weak form of participation or as a means of legitimizing decisions that have already been made.

An inherent danger in conceiving consultation as a means of legitimizing decisions that have already been made is that it reinforces the rhetoric that persons likely to be displaced are necessary sacrifices for the realization of development. Regarding consultation as a weak form of participation defeats the object and purpose of the Convention. This approach should be discarded.

In understanding its object and purpose, it is relevant to consider specific provisions of the Convention, including its preamble, which is "the natural place in which to look for, an express or explicit general statement of the treaty's objects and purposes". ${ }^{66}$ Paragraph 3 of the preamble emphasizes the commitment of states to "providing durable solutions" as an underlying reason for the creation of the Convention. Under article 11(1), states are obligated to "seek lasting solutions to the problem of displacement by promoting and creating satisfactory conditions for voluntary return, local integration or relocation on a sustainable basis". A significant indicator of durable solutions emphasized by the Inter-Agency Standing Committee on Durable Solutions

contd

requiring that persons likely to be displaced "shall have full access to information on the reasons and procedure for the displacement, and where applicable, also information on compensation and relocation".

62 This element of consultation reverberates strongly in the Kenyan Prevention, Protection and Assistance of Internally Displaced Persons and Affected Communities Act as a pertinent condition in the formulation of durable solutions: Act No 56 (2012), arts 8 (3), 9 and 22.

63 BC Smith "Participation without power: Subterfuge or development?" (1998) 33/3 Community Development Journal 197 at 198.

64 A Cornwall "Unpacking 'participation': Models, meanings and practices" (2008) 43/3 Community Development Journal 269 at 270.

65 The Brookings Institution and University of Bern Project on Internal Displacement Moving Beyond Rhetoric: Consultation and Participation with Populations Displaced by Conflict or Natural Disasters (2008, Brookings Institute) at 4.

66 IM Sinclair The Vienna Convention on the Law of Treaties (1984, Manchester University Press) at 128 . 
for IDPs (IASC) is that such solutions must result in a situation where IDPs "no longer have any specific assistance and protection needs that are linked to their displacement and [as such] can enjoy their human rights without discrimination on account of their displacement". ${ }^{67}$ The idea that resonates from this fact is that durable solutions should involve "a workable balance between the development agenda and protection schemes for communities already displaced or in danger of being displaced". ${ }^{68}$ In achieving a workable balance, there must necessarily be an agreement between the state and the persons likely to be displaced. However, such an agreement cannot be realized where consultation is regarded as a means of merely gathering opinions or legitimizing decisions that have already been made.

Interpreting "consultation" merely as a means of gathering opinions or legitimizing decisions that have already been made also goes against the obligation on states to formulate development plans based on the active, free and meaningful participation of persons involved. ${ }^{69}$ Active, free and meaningful participation of individuals in development processes contemplates a purposeful engagement of individuals in development plans, programmes and projects (bound to affect them) in a manner devoid of coercion. Such participation must necessarily be a two-way process and should drive development outcomes. It cannot be conceived as a process of legitimizing decisions that have already been made. Hence, if states are to ensure free, active and meaningful participation in development processes, "consultation" cannot merely be a form of legitimizing decisions that have already been made relating to development projects. Having emphasized that consultation cannot be regarded as a means of merely gathering opinions or legitimizing decisions that have already been made, an important question that needs to be answered is how the process of consultation should be understood. The authors contend that it is pertinent to implement consultation in light of African customs and traditions under which systems consultation is a consensual decision-making process and not a means of legitimizing decisions that have been finalized. Article 7(3)(c) of the Guiding Principles on Internal Displacement ${ }^{70}$ aligns itself with this by requiring states to seek the free, prior and informed consent of persons likely to be displaced. With respect to mining projects, the ECOWAS Directive on the Harmonisation of Guiding Principles and Policies in the Mining Sector sets a best practice standard in requiring that the free, prior and informed consent of local communities must be obtained before the implementation of mining projects. ${ }^{71}$ It is

67 IASC Framework on Durable Solutions for IDPs (2010) at A-1.

68 Juma "Protection of development-induced internally displaced persons", above at note 9 at 224 .

69 Development Declaration, art 2(3).

70 Above at note 42.

71 ECOWAS Directive on the Harmonization of Guiding Principles and Policies in the Mining Sector (2009), art 16(3). While operationalization of this Guiding Principle is yet to be seen, Ghana gazetted this directive in 2011. See Ghana Investment 
pertinent that, in consultative processes, groups that are likely to be marginalized are significantly represented. In the IBCSP, the Batwa peoples were not adequately consulted.

As it is likely that specific groups, such as persons with disabilities, indigenous populations and the elderly, may be marginalized in consultative processes, it is important that appropriate safeguards are adopted. For women, an important measure could be women-specific focus groups. For children, cultural hindrances to participation must also be addressed to ensure that the process is child-friendly.

When consultation is geared towards building consent, project sustainability is enhanced, the risk of conflict is lessened and livelihood reconstruction for those displaced can be better realized. ${ }^{72}$

\section{Least restrictive means}

Central to the least restrictive means requirement is the need to ensure that displacement is carried out as a last resort. ${ }^{73}$ This element requires states to ensure that other alternatives to a proposed development project are given due consideration. ${ }^{74}$ The least restrictive means requirement, also known as the necessity test, is encapsulated in article 10(2) of the Convention as "feasible alternatives". Although the Convention does not provide explicitly for feasible alternatives to a proposed development project, there are six alternatives that should be considered in the context of CBDID.

The first alternative is the no-action alternative. ${ }^{75}$ This alternative implies that the possibility should be considered of not implementing a project bound to orchestrate displacement. This alternative is derived from the need to prevent displacement altogether. However, as the duty in article 10

contd

Promotion Centre "Ghana gazettes ECOWAS directives on mining sector" (2011), available at: <http://www.gipcghana.com/press-and-media/144-ghana-gazettes-ecowasdirectives-on-mining-sector.html> (last accessed 8 July 2018).

72 See A Niber et al The Right to Decide: Free Prior Informed Consent in Ghana (report by Wassa Association of Communities Affected by Mining and Center for Public Interest Law, 3 March 2015).

73 Res on the Right to Adequate Housing and Protection from Forced Evictions, adopted at the 52nd ordinary session of the African Commission on Human and Peoples' Rights, Yamoussoukro, Côte d'Ivoire (9-22 October 2012) in C Heyns and M Killander Compendium on Key Human Rights Documents of the African Union (2013, Pretoria University Law Press) 442 at 443.

74 The essence of this element derives from the need to mitigate the impact of internal displacement, which resonates as an important theme in the prevention of arbitrary displacement. See Zambian Guidelines, para 10.

75 UN Basic Principles and Guidelines on Development-Based Evictions and Displacement, UN doc A/HRC/4/18, annex I (5 February 2007) (Kothari Principles), para 40; Organisation for Economic Cooperation and Development "Guidelines for aid agencies on involuntary displacement and resettlement in development projects" (1992) at 6. 
(1) of the Convention is not absolute, this alternative may not always be achievable.

A second alternative that states should consider is the option of implementing a project in a location where displacement may not occur. For forest conservation projects, this may require a demarcation of indigenous peoples' territories so as to ensure that their lands are not encroached upon or plundered, as was observed in a study on Batwa during implementation of the IBCSP. ${ }^{76}$ The essence of this alternative relates to the objective of the "no-action" alternative of preventing displacement altogether or implementing the project in a location where only minimal displacement will occur.

Where these two alternatives are not feasible, a third alternative that should be explored is the option of implementing the project in collaboration with persons likely to be displaced. The Biodiversity Conservation Project initiated to preserve the biodiversity of the Amazon forest in Pastaza province of Ecuador is a good example of this alternative being put in place. ${ }^{77}$ The Quichua communities of Yana Yacu, Nina Amarun and Loracachi, comprising about 300 indigenous peoples in Pastaza Province, were engaged for the implementation of this project. ${ }^{78}$ Capacity-building programmes, comprising a mixed team of scientific experts and indigenous specialists, were initiated to enable members of the communities to implement the project. ${ }^{79}$ In the implementation of the project, the Quichua communities initiated an Inter-Community Biological Conservation Zone that brought together locations in the delta of major tributaries with a rich diversity of flora and fauna. ${ }^{80}$ The success of this initiative surpassed initial expectations. Further, the capacity building exercise enabled the sustainability of conservancy efforts as each of the communities had "trained technicians that ... [could] support future territorial planning and natural resource management processes". 81 In the NRMP, a collaborative effort would have been a good alternative given that the Sengwer peoples had a rich traditional knowledge of the flora and fauna in the Embobut Forest.

In situations where this alternative is not feasible, strategies for reducing displacement should be considered. ${ }^{82}$ In close proximity to the minimization of displacement is the fifth alternative of modifying project designs. Where

76 Adrien "The DRC case study", above at note 24 at 65.

77 World Bank Project Completion Report Ecuador: Pastaza Biodiversity Conservation Project (GEF MSP grant no TF-051726-EC, Bolivia, Ecuador, Peru and Venezuela Country Managing Unit, Environmentally and Socially Sustainable Development Sector Unit, Latin America and the Caribbean Region, World Bank, 5 September 2006).

78 Id at 6; M Ying and Y Watanabe "Indigenous peoples and the GEF" (1 May 2013) GEF-CSO Network.

79 World Bank Project Completion Report, above at note 77 at 22.

80 Id at 7; Global Environment Facility Indigenous Communities and Biodiversity (2008, Global Environment Facility Publications) at 23.

81 World Bank, id at 23.

82 Kothari Principles, para 31. 
project designs cannot be altered, lease negotiations with affected communities should be considered. In the 1950s, when the Jintsu Gawa Dams were to be created in Japan, the government entered into a lease agreement with the peasant land owners rather than expropriating the land. ${ }^{83}$ The implication of this alternative is that ownership of the land remains with persons likely to be displaced within the duration of a project. Where projects are to be permanent, this alternative may not achievable.

However, as the obligation to prevent CBDID is not absolute, involuntary displacement may occur "only as a last resort", ${ }^{84}$ but this must be accompanied by fair and just compensation. Article 12 of the Convention requires states to "establish an effective legal framework to provide just and fair compensation and other forms of reparations, where appropriate, to internally displaced persons for damage incurred as a result of displacement, in accordance with international standards". It is important that displacement must never have as a consequence a situation where certain categories of persons, such as women, children or persons with disabilities, are left impoverished. As such, states must ensure that the specific needs of these categories are given due consideration in the implementation of compensation policies. CBDIDPs should be allowed to choose the type of compensation, whether land based, monetary or both.

\section{Conclusion}

The Convention is ground-breaking in its legal protection in article 5(4) of climate change internally displaced populations. However, there should be normative clarity about states' obligations with respect to specific issues including displacement due to climate change, which has emerged as a significant global challenge. One of the areas of displacement due to climate change is CBDID. Article 10 of the Convention obligates states "as much as possible" to prevent displacement caused by development projects including CBDID. The phrase "as much as possible" as a yardstick in the Convention for measuring arbitrary CBDID lacks clarity. This article has argued that in understanding "as much as possible", which contemplates the prevention of arbitrary CBDID, public and private actors must adhere to due process.

This article has also argued that there are key due process requirements that must be complied with, namely prior-impact assessments, information, consultation and least restrictive means. These requirements follow from the provisions of article 10(2) and (3), that are integral to article 10(1). Article 10(2) of

83 MM Cernea "Compensation and investment in resettlement: Theory, practice, pitfalls, and needed policy reform" in MM Cernea and HM Mathur (eds) Can Compensation Prevent Impoverishment? Reforming Resettlement Through Investments and Benefit-Sharing (2008, Oxford University Press) 15 at 78.

84 The element of "last resort" is specifically emphasized in Somaliland's IDP policy. See Somaliland Internal Displacement Policy, 2016, para 4.4.1(iv). See also Res on the Right to Adequate Housing, above at note 73 at 443. 
the Convention requires states to explore feasible alternatives to climate-based development projects with the full information and consultation of persons likely to be displaced, while article 10(3) requires states to conduct prior socioeconomic and environmental impact assessments before the implementation of climate-based development projects. There are six feasible alternatives that should be explored before displacement. However, where these alternatives cannot be realized, it is important for states to ensure that CBDID is carried out in a manner that respects human dignity and protects vulnerable groups.

In operationalizing the obligation in the Convention, this article has argued that it is important for states to domesticate those obligations. States must ensure that institutions exist for operationalizing the due process requirements. Moreover, supranational institutions such as the African Commission and the Conference of State Parties have essential roles to perform. The African Commission should develop a General Comment specifically on article 10 of the Convention to clarify the obligation of states to prevent CBDID "as much as possible". 